OPEN ACCESS

Edited by:

Enikö Kallay,

Medical University of Vienna, Austria

Reviewed by:

Jie Liu,

Fourth Military Medical University,

China

Michael Mannstadt,

Massachusetts General Hospital, USA

*Correspondence:

Arthur D. Conigrave

arthur.conigrave@sydney.edu.au

Specialty section:

This article was submitted to Integrative Physiology, a section of the journal

Frontiers in Physiology

Received: 10 September 2016 Accepted: 07 November 2016 Published: 15 December 2016

Citation:

Conigrave $A D$ (2016) The Calcium-Sensing Receptor and the Parathyroid: Past, Present, Future. Front. Physiol. 7:563.

doi: 10.3389/fphys.2016.00563

\section{The Calcium-Sensing Receptor and the Parathyroid: Past, Present, Future}

\author{
Arthur D. Conigrave* \\ Faculties of Science and Medicine, School of Life and Environmental Sciences, Charles Perkins Centre, University of Sydney, \\ Sydney, NSW, Australia
}

Parathyroid hormone (PTH) defends the extracellular fluid from hypocalcemia and has powerful and well-documented actions on the skeleton and renal tubular system. To achieve a satisfactory stable plasma calcium level, the secretion of PTH, and the resulting serum $\mathrm{PTH}$ level, is titrated carefully to the prevailing plasma ionized $\mathrm{Ca}^{2+}$ concentration via a $\mathrm{Ca}^{2+}$ sensing mechanism that mediates feedback inhibition of PTH secretion. Herein, I consider the properties of the parathyroid $\mathrm{Ca}^{2+}$ sensing mechanism, the identity of the $\mathrm{Ca}^{2+}$ sensor, the intracellular biochemical mechanisms that it controls, the manner of its integration with other components of the PTH secretion control mechanism, and its modulation by other nutrients. Together the well-established, recently elucidated, and yet-to-be discovered elements of the story constitute the past, present, and future of the parathyroid and its calcium-sensing receptor (CaSR).

Keywords: calcium-sensing receptor, parathyroid, phospholipase C, adenylate cyclase, heterotrimeric G proteins, Calcimimetics, calcilytics, mineral metabolism

\section{INTRODUCTION}

The parathyroid gland elaborates a peptide hormone, parathyroid hormone (PTH) whose primary role is to prevent and/or reverse acute hypocalcemia. It achieves this by: mobilizing calcium from stores in bone; stimulating renal $\mathrm{Ca}^{2+}$ reabsorption; and promoting the production of $1,25-$ dihydroxyvitamin $\mathrm{D}_{3}$ to drive intestinal calcium absorption. To prevent uncontrolled elevations in plasma calcium concentration in response to $\mathrm{PTH}$, a molecular feedback mechanism mediated by the extracellular $\mathrm{Ca}^{2+}$ ion concentration $\left(\mathrm{Ca}^{2+}{ }_{\mathrm{o}}\right)$ suppresses PTH secretion from the cells of the gland (review: Conigrave and Ward, 2013). While this mechanism operates primarily on parathyroid chief cells, which are the most numerous cell type and major site of PTH production, it may also operate on a second less numerous cell type, the parathyroid oxyphil cells (Ritter et al., 2012). In addition to providing acute control of PTH secretion from both newly-formed secretory vesicles and stored secretory granules, the $\mathrm{Ca}^{2+}$-mediated feedback mechanism also suppresses the transcription of the PreProPTH gene and cell proliferation (review: Brown and MacLeod, 2001). Herein, I provide an account of how the pivotal parathyroid $\mathrm{Ca}^{2+}$ sensing mechanism was first characterized and how key biochemical features of the signaling mechanisms were exploited to clone the class C G-protein coupled receptor (GPCR) we now know as the calcium-sensing receptor (CaSR). I go on to describe how studies of this receptor in these cells have led to deep understandings of parathyroid function in health and disease and new approaches to therapies for various disorders of calcium metabolism and parathyroid function. 


\section{THE PAST}

\section{In vivo and In vitro Evidence for a Parathyroid $\mathrm{Ca}^{2+}$ Sensing Mechanism}

Surgical removal of the parathyroid glands, whether intentional or inadvertent, induces acute, and in some cases catastrophic, hypocalcemia in experimental animals and in humans (e.g., MacCallum and Voegtlin, 1909; MacCallum et al., 1914; Westerdahl et al., 2000; Vasher et al., 2010; Salinger and Moore, 2013). In addition, perturbations of the plasma ionized calcium concentration in vivo by intravenous infusions of calcium salts to induce hypercalcemia or $\mathrm{Ca}^{2+}$ chelators such as citrate or EGTA to induce hypocalcemia provoke rapid negative and positive changes in the serum PTH concentration respectively (Fox and Heath, 1981; Conlin et al., 1989; Schwarz et al., 1992). These studies demonstrate that the gland is equipped with a $\mathrm{Ca}^{2+}$. sensor that suppresses PTH secretion in response to elevated $\mathrm{Ca}^{2+}$ concentration.

The successful preparation of bovine parathyroid cells using collagenase digestion of sliced parathyroid gland tissue provided novel opportunities to assess the cellular $\mathrm{Ca}^{2+}$ sensing mechanism in vitro (Brown et al., 1976) and similar observations were made for porcine (Morrissey and Cohn, 1978) and also human (Birnbaumer et al., 1977; Brown et al., 1978a, 1979a; Conigrave et al., 2004) parathyroid cells. In all these cases, mammalian parathyroid cells in primary culture supported a robust endogenous secretion of PTH that was promptly shut off upon elevation of $\mathrm{Ca}^{2+}{ }_{0}$. In cells prepared from samples of parathyroid tissue derived from patients with primary hyperparathyroidism there was impairment but not complete loss of $\mathrm{Ca}^{2+}{ }_{\text {o }}$ sensitivity (Brown et al., 1979a,c; Mun et al., 2009). The behavior raises questions about the nature of the extracellular $\mathrm{Ca}^{2+}$ sensor. It also raises questions about the nature of the intrinsic/endogenous PTH secretion mechanism.

In the first description of a viable, functional parathyroid cell preparation (Brown et al., 1976) bovine parathyroid cells in primary culture in Eagle's medium (minus bicarbonate) secreted PTH linearly at a rate of 20-30 pmol cell ${ }^{-1} \mathrm{~h}^{-1}$ for up to $3 \mathrm{~h}$. PTH secretion was suppressed by around $60 \%$ at a $\mathrm{Ca}^{2+}$ o of $1.5 \mathrm{mM}$ when compared to that observed at $0.5 \mathrm{mM} \mathrm{Ca}^{2+}{ }_{0}$. In the presence of $0.5 \mathrm{mM} \mathrm{Ca}^{2+}{ }_{0}$, elevated extracellular $\mathrm{Mg}^{2+}$ concentration $\left(\mathrm{Mg}^{2+}{ }_{\mathrm{o}}\right)$ also suppressed PTH secretion although $\mathrm{Mg}^{2+}$ o was less potent than $\mathrm{Ca}^{2+}{ }_{0}$. Finally, increases in PTH secretion were observed in response to the $\beta$ adrenergic agonist isoproterenol that were partially reversed by the $\beta$-adrenergic antagonist propranolol (Brown et al., 1976). Thus, key features of the preparation included: $\mathrm{Ca}^{2+} \mathrm{o}^{-}$and $\mathrm{Mg}^{2+}{ }_{\mathrm{o}}$-mediated suppression of $\mathrm{PTH}$ secretion, pointing to the existence of an intrinsic divalent cation sensor with a preference for $\mathrm{Ca}^{2+}{ }_{0}$ over $\mathrm{Mg}^{2+}{ }_{0}$; and stimulation of $\mathrm{PTH}$ secretion by cAMP-linked GPCRs including beta-adrenergic, dopaminergic, and prostanoid receptors (Brown et al., 1977a,b; Gardner et al., 1980). These findings pointed to the existence of neuronal, hormonal, and/or local stimulatory control of PTH secretion. Although not clearly identified, the findings also demonstrated the existence of an intrinsic PTH secretion mechanism. According to one interpretation, parathyroid cells are equipped with a constitutive PTH secretion mechanism. According to an alternative interpretation, parathyroid cells respond to an autocrine/paracrine mechanism that supports $\mathrm{PTH}$ secretion.

\section{The Concept of a Calciostat and an Extracellular $\mathrm{Ca}^{2+}$ Set-Point}

The $\mathrm{Ca}^{2+}$-sensing mechanism in the parathyroid supports the operation of an extracellular "calciostat" in vivo. The set-point for this calciostat occurs at a plasma ionized $\mathrm{Ca}^{2+}$ concentration of around 1.1-1.2 $\mathrm{mM}$ corresponding to plasma total calcium concentrations of around $2.2-2.4 \mathrm{mM}$, of which approximately half is in an albumin-bound form. PTH secretion rates rise 2 to 4 -fold as $\mathrm{Ca}^{2+}$ o drops toward $1.0 \mathrm{mM}$ and are effectively suppressed by $>50 \%$ as $\mathrm{Ca}^{2+}{ }_{0}$ rises toward $1.4 \mathrm{mM}$ (review: Conigrave et al., 2000a). The changes in PTH secretion rate are reflected in consonant changes in the serum PTH level (normal range $1-6 \mathrm{pmol} / \mathrm{L}$ ). This set-point behavior can be readily demonstrated in perifused parathyroid cell preparations including those prepared from human parathyroid glands (Conigrave et al., 2004; Figure 1). $\mathrm{Ca}^{2+}{ }_{\mathrm{o}}$-dependent inhibitory control of renal $\mathrm{Ca}^{2+}$ reabsorption, resulting in elevated renal calcium excretion, also contributes to the calciostat function, providing a key element of the defense against hypercalcemia (Kantham et al., 2009; Loupy et al., 2012).

\section{Extracellular $\mathrm{Ca}^{2+}$-Mediated Signaling Mechanisms cAMP Promotes PTH Secretion via a $\mathrm{Ca}^{2+}$-Sensitive Pathway}

Suppression of cAMP levels accompanies high $\mathrm{Ca}^{2+}{ }_{\mathrm{o}}$-induced suppression of PTH secretion in parathyroid cells stimulated to secrete by exogenous agonists of $\mathrm{G}_{\mathrm{s}}$-coupled GPCRs (Brown et al., 1977a, 1979b, 1978b, 1985; Windeck et al., 1978) and also in cells not exposed to exogenous GPCR activators, in which intracellular cAMP levels are typically much lower $(\leq 5 \%$ of those in stimulated cells; Brown et al., 1978b). Excellent correlations were observed between cAMP levels and PTH secretion rates in these experiments supporting the hypothesis that cAMP is a primary driver of both exogenous GPCRstimulated and intrinsic PTH secretion (Brown et al., 1978b). Similar results were obtained in a comparative analysis of the effects of divalent and tervalent cations on PTH secretion and cAMP accumulation (Brown et al., 1990). If this is so, the mechanisms of $\mathrm{Ca}^{2+}{ }_{\mathrm{o}}$-dependent suppression of cAMP levels and PTH secretion are different under the conditions of (i) exogenous, GPCR-stimulated and (ii) spontaneous PTH secretion. This follows because pertussis toxin disabled $\mathrm{Ca}^{2+}{ }_{\mathrm{O}^{-}}$ and divalent/tervalent cation-induced suppression of dopaminestimulated PTH secretion (Chen et al., 1989; Brown et al., 1990), demonstrating that $G_{i}$ is required for inhibitory control of PTH secretion downstream of cAMP-linked GPCRs, but pertussis toxin had no dis-inhibitory effect on high $\mathrm{Ca}^{2+}{ }_{\mathrm{o}}$-mediated suppression of intrinsic PTH secretion i.e., in the absence of exogenous GPCR activators (Brown et al., 1992). Findings in support of the hypothesis that pertussis toxin suppresses both 

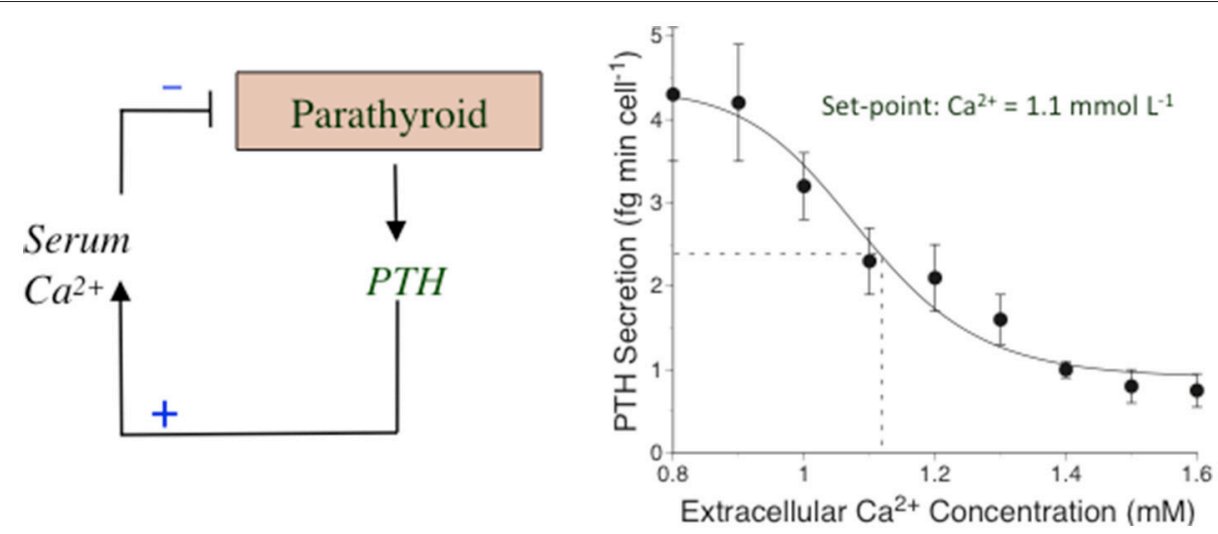

FIGURE 1 | The calciostat in parathyroid cells. Left: A representation of the feedback mechanism by which PTH elevates the serum Ca ${ }^{2+}$ concentration and $\mathrm{Ca}^{2+}$ feeds back on the parathyroid to suppress PTH secretion in a process mediated by the CaSR. Right: Human parathyroid cells were perifused with HEPES-buffered physiological saline solutions containing various $\mathrm{Ca}^{2+}$ concentrations and samples of perifusate were collected at various times and subsequently analyzed for PTH1-84 as described in Conigrave et al. (2004). The results have been re-drawn. *Total and ionized calcium concentrations are comparable in serum and plasma since the major calcium-binding protein, albumin is present in similar concentrations in both these fluids.

exogenous GPCR-stimulated and endogenous PTH secretion (Fitzpatrick et al., 1986a) have not been confirmed.

The results suggest the existence of an extracellular $\mathrm{Ca}^{2+}$ sensor that is capable of activating $G_{i}$ to suppress cAMP synthesis and, in turn, cAMP-linked PTH secretion in the presence of exogenous agonists that markedly elevate cAMP levels. The lack of association between $G_{i}$, cAMP levels, and PTH secretion in parathyroid cells NOT exposed to exogenous GPCR activators, on the other hand, points to a distinct biochemical mechanism arising either from a second $\mathrm{Ca}^{2+}$ sensor or from a single $\mathrm{Ca}^{2+}$ sensor that couples to distinct downstream signaling pathways depending on whether the cells have been stimulated to secrete PTH by exogenous activators or are operating spontaneously (Figure 2). Support for the hypothesis that the $\mathrm{Ca}^{2+}$ sensing mechanism in parathyroid cells is mediated by $\mathrm{Ca}^{2+}$ channels and controlled by the activity of pertussis toxin-sensitive Gproteins (Fitzpatrick et al., 1986a,b) has not been supported by other studies (e.g., Brown et al., 1992). More recent work has implicated $\mathrm{G}_{\mathrm{q} / 11}$ and, possibly, phosphatidylinositol-specific phospholipase $\mathrm{C}$ (PI-PLC) and $\mathrm{ERK}_{1 / 2}$ downstream of an extracellular $\mathrm{Ca}^{2+}$ sensing GPCR (see below).

\section{Intracellular $\mathrm{Ca}^{2+}$ Mobilization and PI-PLC}

An alternative signaling pathway, downstream of an extracellular $\mathrm{Ca}^{2+}$ sensor was subsequently identified in populations of bovine parathyroid cells loaded with the cell-permeant $\mathrm{Ca}^{2+}$-sensitive fluorophore fura-2AM. The cells exhibited robust intracellular $\mathrm{Ca}^{2+}$ transients in response to elevated $\mathrm{Ca}^{2+}$ o suggesting the action of a PI-PLC coupled GPCR that senses increases in $\mathrm{Ca}^{2+}{ }_{\mathrm{o}}$ (Nemeth and Scarpa, 1986, 1987a). Furthermore, they exhibited similar intracellular $\mathrm{Ca}^{2+}$ transients in response to elevated $\mathrm{Mg}^{2+}$ or $\mathrm{Sr}^{2+}$ concentration consistent with the observations referred to above that the parathyroid $\mathrm{Ca}^{2+}$ sensing mechanism is promiscuous with respect to divalent cations (Chen et al., 1989; Brown et al., 1990). To investigate whether the parathyroid $\mathrm{Ca}^{2+}$ sensor might indeed be a PI-PLC coupled GPCR, further studies demonstrated that $\mathrm{Ca}^{2+}, \mathrm{Mg}^{2+}$ and other inorganic divalent cations promoted the production of water-soluble $\left[{ }^{3} \mathrm{H}\right]$-inositol phosphates from [ $\left.{ }^{3} \mathrm{H}\right]$-inositol labeled cells (Brown et al., 1987; Shoback et al., 1988).

\section{A Promiscuous Divalent/Multivalent Cation Sensor}

Investigation of the molecular requirements for divalent cation sensing in parathyroid cell preparations led to some surprising observations. Firstly, tervalent inorganic cations of the lanthanide group including $\mathrm{Gd}^{3+}$ and $\mathrm{Tb}^{3+}$ were found to be high potency activators $\left(\mathrm{EC}_{50} \approx 5-50 \mu \mathrm{M}\right)$ of parathyroid PIPLC, suppressors of GPCR-stimulated CAMP accumulation, and inhibitors of PTH secretion (Brown et al., 1990) in a manner analogous to divalent cations. Furthermore, and even more surprisingly, organic multivalent cations including polyarginine, polylysine, and protamine (Brown et al., 1991a), the PLC inhibitor neomycin (Brown et al., 1991b), and polyamines such as spermine (Nemeth and Scarpa, 1987b) stimulated intracellular $\mathrm{Ca}^{2+}$ mobilization and inhibited PTH secretion.

\section{Expression Cloning of a Polyvalent Cation-Sensing Receptor from a Bovine Parathyroid cDNA Library}

The demonstration that the parathyroid calcium sensor coupled to the activation of PI-PLC and, at least in certain circumstances, to heterotrimeric $G_{i}$ G-proteins, and was promiscuous with respect to inorganic and organic multivalent cations provided a strategy by which a putative PLC-coupled receptor might be cloned by cellular expression of pools of mRNA derived from a size-fractionated bovine parathyroid cDNA library (Brown et al., 1993). Xenopus oocytes express a large conductance $\mathrm{Cl}^{-}$ channel whose open probability is highly sensitive to changes in intracellular $\mathrm{Ca}^{2+}$ concentration (e.g., downstream of GPCRmediated generation of $\mathrm{IP}_{3}$ and intracellular $\mathrm{Ca}^{2+}$ mobilization). 


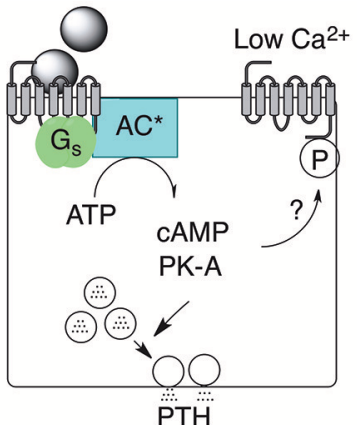

PTH
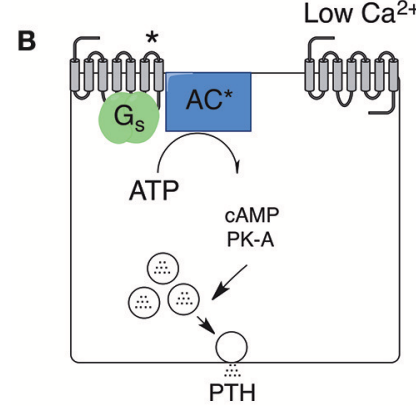

FIGURE 2 | Stimulated and spontaneous mechanisms in support of PTH secretion and its inhibition by high $\mathrm{Ca}^{2+}{ }_{0}$. PTH secretion and its inhibition by high $\mathrm{Ca}^{2+}$ o arises from two distinct mechanisms. One mechanism is supported by exogenous agonists, including neurotransmitters or hormones, that activate $\mathrm{G}_{\mathbf{S}}$-coupled GPCRs as shown in (A) (left and right). PTH secretion continues provided $\mathrm{Ca}^{2}{ }^{+}$o remains low but is promptly inhibited by $\mathrm{G}_{\mathrm{i}}$-dependent inhibition of adenylate cyclase in the presence of high $\mathrm{Ca}^{2+}$ o. The mechanism by which the $\mathrm{Ca}^{2+}$ o sensor, now known to be the CaSR, preferentially binds to $G_{i}$ in this context is not known but might depend on local protein kinase-A (PK-A) activation. A second mechanism occurs spontaneously and may be supported by constitutive $\mathrm{G}_{\mathrm{S}}$-coupled GPCR activity (as shown in $\mathbf{B}$; left and right) or by autocrine/paracrine production of receptor activators. PTH secretion via this second mechanism continues provided $\mathrm{Ca}^{2+}$ o remains low but is inhibited by high $\mathrm{Ca}^{2+}{ }_{0}$-induced $\mathrm{G}_{\mathrm{q} / 11}$-dependent activation of intracellular $\mathrm{Ca}^{2+}$ mobilization or $\mathrm{Ca}^{2+}$ influx (not shown). One possible mechanism by which increased intracellular free $\mathrm{Ca}^{2+}$ concentration $\left(\mathrm{Ca}^{2+}{ }_{j}\right)$ suppresses PTH secretion is shown via $\mathrm{Ca}^{2+}{ }_{i}$-dependent inhibition of adenylate cyclase. ${ }^{*}$ Receptor activated in the absence of neuronal or hormonal stimuli.

In this case, the successful cloning of the novel class C GPCR that is now referred to as "the calcium-sensing receptor" relied on its high degree of sensitivity to $\mathrm{Gd}^{3+}$, which was used to identify "active" pools of mRNA for further separation and purification. Once cloned, the receptor was readily expressed not only in Xenopus oocytes but also various mammalian cell lines including HEK-293 cells and was found to exhibit sensitivity not only to divalent inorganic cations including $\mathrm{Ca}^{2+}$ and $\mathrm{Mg}^{2+}$, and tervalent inorganic cations including $\mathrm{Gd}^{3+}$ but also to organic cations including the antibiotic neomycin (Brown et al., 1993), polyamines such as spermine (Quinn et al., 1997), cationic polypeptides such as polyarginine and polylysine (Ray and Northup, 2002), and cationic proteins including beta amyloid (Ye et al., 1997). The cloning of the bovine parathyroid CaSR was followed subsequently by the cloning of its orthologs from human parathyroid (Garrett et al., 1995), rat kidney (Riccardi et al., 1995), and rat brain (Ruat et al., 1995).

The CaSR is known now to be expressed widely, with various $\mathrm{Ca}^{2+}{ }_{\mathrm{o}}$-dependent and non-Ca ${ }^{2+}{ }_{\mathrm{o}}$ dependent functions in cell and developmental biology as detailed elsewhere in this issue. It is also known to activate a large number of signaling pathways downstream of various G-proteins and multiple cell membraneassociated as well as cytoplasmic enzymes (review: Conigrave and Ward, 2013).

The CaSR mediates, for example, the activation of various protein kinases including protein kinase $\mathrm{C}$ isoforms, which negatively modulate CaSR function (Jiang et al., 2002; Davies et al., 2007; Lazarus et al., 2011; Young et al., 2014), and the mitogen activated protein (MAP) kinases ERK $1 / 2$, p38 and JNK (Kifor et al., 2001; Tfelt-Hansen et al., 2003; review: Conigrave and Ward, 2013). The roles of protein kinases in CaSR-mediated inhibitory control of PTH secretion are not well-understood but $\mathrm{ERK}_{1 / 2}$ appears to contribute (Corbetta et al., 2002) and could be activated downstream of either $\mathrm{G}_{\mathrm{q} / 11}$ or $\mathrm{G}_{\mathrm{i}}$ (review: Conigrave and Ward, 2013).

While the CaSR is expressed and trafficked to the plasma membrane as functional homodimers (Bai et al., 1998, 1999) that couple efficiently to $\mathrm{G}_{\mathrm{q} / 11}$, it is also capable of forming heterodimers with other members of GPCR family $\mathrm{C}$ including metabotropic glutamate receptors (Gama et al., 2001) and $\mathrm{GABA}_{\mathrm{B}}$ receptors, especially GABA $\mathrm{B}_{\mathrm{B}}$ (Chang et al., 2007; Cheng et al., 2007). The consequences of heterodimerization for receptor localization to specific subdomains of the plasma membrane and for signaling pathway selection in different tissues and for the parathyroid, in particular, are not yet clear.

\section{Physiological and Clinical Significance of the CaSR for Parathyroid Function Parathyroid and Mineral Disorders Linked to CaSR Mutations (and Anti-CaSR Antibodies)}

As the bovine parathyroid, rat kidney, and human parathyroid CaSR cDNAs were cloned (Brown et al., 1993; Garrett et al., 1995; Riccardi et al., 1995), it became possible to assess whether any recognized human disorders of calcium metabolism and/or parathyroid function arose from mutations of the CaSR. This was rapidly confirmed for two hypercalcemic disorders in which the CaSR is hypofunctional: the uncommon disorder known as familial hypocalciuric hypercalcemia $(\mathrm{FHH})$; and the extremely rare disorder known as neonatal severe hyperparathyroidism (NSHPT; Pollak et al., 1993, 1994; reviews: Brown et al., 1995; Hendy et al., 2000). It was subsequently also confirmed for the hypocalcemic disorder known as autosomal dominant hypocalcemia (ADH; Pearce et al., 1996) in which the CaSR is hyperfunctional.

\section{$\mathrm{FHH}$}

Deactivating, typically heterozygous, mutations of the CaSR gene in $\mathrm{FHH}$ result in impaired or disabled $\mathrm{Ca}^{2+}{ }_{\mathrm{o}}$-dependent inhibition of renal $\mathrm{Ca}^{2+}$ reabsorption, leading to hypocalciuria, and as well as impaired $\mathrm{Ca}^{2+}{ }_{\mathrm{o}}$-dependent feedback inhibition of PTH secretion, typically without frank elevations in the serum PTH level as a result of associated increases in $\mathrm{Ca}^{2+}{ }_{\mathrm{o}}$ 
(Chu et al., 1995; review: Brown et al., 1995). Instead, the setpoint for $\mathrm{Ca}^{2+}{ }_{\mathrm{o}}$-dependent suppression of PTH secretion rises thereby increasing the value of the calciostat and the steadystate $\mathrm{Ca}^{2+}{ }_{\mathrm{o}}$ adopts this new level. The primary driver for the increase in $\mathrm{Ca}^{2+}$ o appears to be impaired renal calcium excretion, resulting in characteristic hypocalciuria $(\mathrm{uCa} / \mathrm{Cr}$ ratio $<0.04 \mathrm{mmol} \mathrm{mmol}^{-1}$; $\mathrm{uCa}$ excretion $<1.5 \mathrm{mmol} \mathrm{d}^{-1}$ ). With the identification of two variants of $\mathrm{FHH}$ arising from mutations of two other genes, G $\alpha 11$ and AP2S (see below), the major form of $\mathrm{FHH}$ that arises from mutations of the CaSR has been recently renamed $\mathrm{FHH} 1$.

\section{NSHPT}

In contrast to $\mathrm{FHH}$, homozygous or compound heterozygous deactivating mutations of the CaSR gene have been linked to a severe hypercalcemic disorder that presents in neonatal life with total plasma calcium concentrations that may exceed $4.0 \mathrm{mM}$ (Ward et al., 2004). In addition, there are marked elevations in the serum PTH level, indicative of near-total failure of $\mathrm{Ca}^{2+}{ }_{\mathrm{O}^{-}}$ mediated feedback control of PTH secretion along with skeletal demineralization and pathological fractures (Pollak et al., 1993; review: Brown et al., 1995). The disorder responds promptly to total parathyroidectomy i.e., excision of all four parathyroid glands (Marx et al., 1986) demonstrating that the bone disease is driven by severe primary hyperparathyroidism.

Whether still more severe disorders of skeletal development and metabolism might arise from other types of CaSR mutations is not yet clear. Recently developed mouse models, however, suggest that this is so (Chang et al., 2008; Richard et al., 2010; reviews: Goltzman and Hendy, 2015; Santa Maria et al., 2016). An authoritative database of CaSR mutations and their links to human disease is maintained at: http://www.casrdb.mcgill.ca/.

\section{$A D H$}

Two other rare mineral disorders affecting the parathyroid arise from activating mutations of the CaSR. In one, autosomal dominant hypocalcemia, there is hypocalcemia and inappropriately normal or frankly low serum PTH levels arising from a reduction in the set-point for extracellular $\mathrm{Ca}^{2+}$ (Pearce et al., 1996). One or more of the following may also be observed: hypercalciuria, consistent with enhanced inhibition of renal $\mathrm{Ca}^{2+}$ reabsorption; hypocalciuria (e.g., Tan et al., 2003), consistent with reduced glomerular filtration of $\mathrm{Ca}^{2+}$ ions and a largely intact renal $\mathrm{Ca}^{2+}$ reabsorption mechanism; hypomagnesemia; and hyperphosphatemia (reviews: Thakker, 2004; Egbuna and Brown, 2008). This is typically a chronic benign condition, often diagnosed as an incidental finding on plasma biochemical analysis, in which there may be a longstanding history of paresthesiae, intermittent fasciculations and/or contractions of isolated muscle groups. There may also be a history of one or more childhood seizures including febrile convulsions (reviews: Thakker, 2004; Egbuna and Brown, 2008).

In a second disorder, arising from more severe activating mutations of the CaSR, a form of renal salt wasting also occurs. This Bartter Syndrome (type-5) arises from unrestrained CaSR activation on the contraluminal membrane of the thick ascending limb, which disables NKCC2-dependent $\mathrm{NaCl}$ reabsorption (reviews: Gamba and Friedman, 2009; Riccardi and Brown, 2010).

The impact of gene dosage on the severity of autosomal dominant hypocalcemia has been evaluated in a mouse model, the Nuf mouse (L723Q, affecting a residue at the C-terminal end of iL-2), which exhibits hypocalcemia, suppressed serum PTH levels, hypocalciuria, hyperphosphatemia, and ectopic mineralization and cataracts (Hough et al., 2004). All aspects of the phenotype were more severe in homozygous when compared to heterozygous mice demonstrating that a gene dosage effect applies in the case of activating as well as inactivating mutations of the CaSR, and it is notable that renal hypophosphaturia occurred in homozygous but not heterozygous Nuf mice consistent with the idea that the CaSR normally suppresses renal phosphate excretion including $\mathrm{PTH}$-induced inhibition of phosphate reabsorption (Riccardi et al., 2000; Ba et al., 2003; reviews: Riccardi and Valenti, 2016) and thus promotes phosphate retention. The disorder is amenable to treatment with negative modulators of the CaSR, also known as calcilytics (see below; Mayr et al., 2016; Nemeth and Goodman, 2016).

\section{Disorders of Calcium Metabolism Arising from Autoantibodies that Target the CaSR}

In addition to the impact of inactivating or activating CaSR mutations on calcium metabolism and parathyroid function as described above, several studies have drawn attention to the clinical impact of autoantibodies that target the CaSR with either inactivating (Kifor et al., 2003; Pallais et al., 2004) or activating (review: Brown, 2009) effects, presumably dependent on the peptide epitope that is recognized. These autoimmune disorders of calcium metabolism resemble other autoimmune endocrinopathies such as Grave's disease (review: Thakker, 2004). In one of these disorders associated with autoimmune polyendocrinopathy, autoantibodies to several CaSR epitopes have been identified corresponding to residues $41-69$ at the receptor's $\mathrm{N}$-terminus, $114-126$ at the dimer interface, and 171195 in the vicinity of the Venus FlyTrap (VFT) domain's binding cleft (Kemp et al., 2010).

\section{Transgenic Mouse Models-Impact of Inactivating CaSR Mutations on Parathyroid Function}

The first reported transgenic mouse in which the CaSR was "knocked out," was homozygous for a 20 bp insertion that disabled incorporation of CaSR exon-5 (referred to as CaSR exon-4 in the paper) into the mature, fully processed mRNA (Ho et al., 1995). CaSR exon-5 encodes residues 465-536 (http://www.casrdb.mcgill.ca) at the extreme C-terminal end of the VFT domain, immediately prior to the start of the Cysteinerich domain. Mice with this genotype exhibited a condition comparable to NSHPT in which homozygotes were normal at birth but exhibited severe growth retardation and markedly reduced muscle power in the days after birth (Ho et al., 1995).

The results of biochemical analyses demonstrated the cardinal features of primary hyperparathyroidism including markedly elevated plasma $\mathrm{Ca}^{2+}$ concentration, suppressed plasma inorganic phosphate concentration, and markedly elevated serum PTH levels. In addition, the parathyroid glands 
were enlarged with prominent chief cell hyperplasia (Ho et al., 1995). These findings are consistent with a severe resistance syndrome arising from markedly impaired $\mathrm{Ca}^{2+}$-dependent feedback control of PTH secretion i.e., with loss of the parathyroid $\mathrm{Ca}^{2+}$ sensor.

Heterozygotes, unlike the homozygotes, were phenotypically normal in the weeks and months after birth but exhibited mild biochemical disturbances consistent with $\mathrm{FHH}$ in humans including mildly elevated plasma $\mathrm{Ca}^{2+}$ concentration, suppressed renal calcium excretion, and inappropriately normal plasma PTH levels. These findings suggest a mildly impaired but intact parathyroid $\mathrm{Ca}^{2+}$ sensing mechanism together with impaired extracellular $\mathrm{Ca}^{2+}$-dependent inhibition of renal $\mathrm{Ca}^{2+}$ reabsorption resulting in an increase in the setpoint of the calciostat.

\section{Is the Parathyroid Equipped with an Alternative Calcium-Sensing Receptor?}

While other class C GPCRs, like the CaSR, exhibit $\mathrm{Ca}^{2+}$-sensing properties (Kubo et al., 1998; Wise et al., 1999; Christiansen et al., 2007) it seems unlikely that the parathyroid is equipped with an alternative CaSR since, as described above, mice that are homozygous for either global (Ho et al., 1995) or tissueselective (Chang et al., 2008) knockouts of the CaSR exhibit a severe, uncompensated form of primary hyperparathyroidism in which the plasma levels of both PTH and calcium are markedly elevated from birth. The phenotype suggests a marked impairment of $\mathrm{Ca}^{2+}{ }_{\mathrm{o}}$-dependent negative feedback on PTH secretion with attendant hyperparathyroidism and PTHdependent bone resorption. Thus, if the parathyroid expresses an alternative or supplementary calcium sensor, it is unable to compensate for loss of the CaSR. It is possible that under some circumstances $\mathrm{Ca}^{2+}$-sensing is mediated not by CaSR homodimers but by CaSR heterodimers involving other members of GPCR family $\mathrm{C}$ including metabotropic glutamate receptors or $\mathrm{GABA}_{\mathrm{B} 1}$ receptors as noted above (Gama et al., 2001; Chang et al., 2007; Cheng et al., 2007).

Previous work suggested a role for $\mathrm{Ca}^{2+}$-permeable channels in the control of PTH secretion based on observations that stereoisomers of the $\mathrm{Ca}^{2+}$ channel modulator 202-791 either inhibited (+202 to 791) or stimulated ( -202 to 791) PTH secretion (Fitzpatrick et al., 1986b), and antibodies that target skeletal muscle $\mathrm{Ca}^{2+}$ channels also modulated PTH secretion (Fitzpatrick et al., 1988). Other $\mathrm{Ca}^{2+}$ channel activators, including maitotoxin (Fitzpatrick et al., 1989), and the diltiazem analog TA-3090 (Chen and Brown, 1990) were also found to inhibit PTH secretion. This work was "turned on its head" by the successful development of "calcimimetics" by structural modification of an L-type $\mathrm{Ca}^{2+}$ channel blocker, fendiline (Nemeth et al., 1998), and the subsequent demonstration that modulation of PTH secretion by these agents arises not from actions on $\mathrm{Ca}^{2+}$ channels but rather the cloned CaSR (Nemeth et al., 2004; review: Nemeth, 2006). Thus, various agents that modulate $\mathrm{Ca}^{2+}$ channel activity can also interact with an allosteric site in the CaSR's heptahelical domain (Leach et al., 2016). Calcimimetics, positive modulators of the CaSR, and calcilytics, negative modulators of the CaSR, are discussed in greater detail below.

Nevertheless, more recent work raises the possibility that $\mathrm{Ca}^{2+}$-permeable channels may indeed contribute to the control of PTH secretion. Thus, parathyroid cells express NMDA receptor subunits and NMDA inhibits PTH secretion (Parisi et al., 2009). While these receptors may contribute to the tonic control of PTH secretion, it is not known whether $\mathrm{Ca}^{2+}$ fluxes arising from the activation of NMDA receptors are sensitive to $\mathrm{Ca}^{2+}{ }_{\mathrm{o}}$ concentration in parathyroid cells. In addition, various amino acids and amino acid analogs are known to interact with the CaSR (Conigrave et al., 2000b, 2004; review: Conigrave and Hampson, 2010) and it is not yet clear whether the inhibitory effect of NMDA on PTH secretion is exerted by the activation of $\mathrm{Ca}^{2+}$-permeable ion channels or via positive modulation of the CaSR.

\section{THE PRESENT}

\section{Development of Calcimimetics and Their Utility in Several Forms of Hyperparathyroidism}

As noted above, calcimimetics were developed from the $\mathrm{Ca}^{2+}$ channel blocker fendiline that induces $\mathrm{Ca}^{2+}{ }_{\mathrm{i}}$ mobilization and suppresses PTH secretion from bovine parathyroid cells (Nemeth et al., 1998; review: Nemeth, 2006). Drug development resulted in a new class of pharmaceuticals, the phenylalkylamine calcimimetics, which are positive allosteric modulators of the CaSR that markedly enhance the sensitivity of CaSR-mediated intracellular signaling pathways to $\mathrm{Ca}^{2+}$ o (Nemeth et al., 1998). Early examples included NPS R467 and NPS R568, which together with their less potent S-isomers have been key agents for the analysis of CaSR-mediated effects in various cell and tissue systems. More recent examples include cinacalcet, an agent that is well-absorbed orally (Nemeth et al., 2004) and is effective clinically in the treatment of both secondary hyperparathyroidism due to chronic kidney disease (Moe et al., 2005; Messa et al., 2008) as well as primary hyperparathyroidism (Peacock et al., 2005, 2011; see also review: Nemeth and Shoback, 2013).

One key effect of calcimimetics is suppression of the serum $\mathrm{PTH}$ level. In primary hyperparathyroidism, for example, in which the plasma total calcium concentration is typically elevated from its normal upper limit of $2.6 \mathrm{mM}$ to around $2.8-3.0 \mathrm{mM}$, oral therapy with cinacalcet suppressed serum PTH levels and restored the plasma calcium concentration into the normal range for up to 12 months or more (Peacock et al., 2005). Another key effect is suppression or even reversal of parathyroid hyperplasia. For example, cinacalcet suppresses parathyroid cell proliferation and reduces gland size in models of primary (Imanishi et al., 2011) and secondary (Colloton et al., 2005; Miller et al., 2012) hyperparathyroidism, and also induces apoptosis in second hyperparathyroidism (Tatsumi et al., 2013).

The demonstration that calcimimetics from the same class and across different classes exhibit different biased signaling profiles (Davey et al., 2012) is encouraging efforts to develop 
new generation calcimimetics in support of tissue-specific CaSR-targeted pharmacotherapy e.g., parathyroid vs. kidney vs. thyroid C-cells (review: Leach et al., 2015). Recent modeling of calcimimetic binding in the CaSR's heptahelical domain suggests that agents such as A265347 with less pronounced biased signaling profiles may bind more deeply in the allosteric pocket (Leach et al., 2016).

More recently, a peptide activator of the CaSR (AMG-416; L-Cys-AcDCys-DAla-(DArg) $)_{2}$-DAla-DArgNH ${ }_{2}$ ) has entered clinical practice for the treatment of patients with secondary hyperparathyroidism on hemodialysis (Bell et al., 2015). Administered intravenously it has superior pharmacokinetics including effective suppression of PTH levels beyond $24 \mathrm{~h}$ (Walter et al., 2013) due, presumably, to its ability to form a di-sulfide with CaSR residue C482 in its extracellular domain (Alexander et al., 2015).

\section{Calcilytics}

Several classes of calcilytics (negative modulators of the CaSR) have been developed. These agents, in general, bind in the $\mathrm{HH}$ domain and suppress CaSR signaling. For this reason, they have proved useful in assessing the role of the CaSR in $\mathrm{Ca}^{2+}$ - or $\mathrm{L}-$ amino acid-induced cellular or tissue responses (e.g., Dvorak et al., 2004; Daly et al., 2013). In the parathyroid, calcilytics promote PTH secretion by reversing the inhibitory action of the CaSR (Nemeth et al., 2001). As a consequence, it was hoped that these agents might prove useful in the treatment of osteoporosis by elevating serum PTH levels to emulate the action of intermittent subcutaneous injections of PTH1-34 (teriparatide). However, none of the calcilytics that have entered human clinical trials, thus far, have been successful in significantly increasing bone density or reducing fracture risk (review: Nemeth and Goodman, 2016). Two main explanations seem reasonable: (i) the maximum increase in the serum level of endogenous $\mathrm{PTH}$ is significantly less than that achieved by subcutaneous injections of PTH1-34 (e.g., Kimura et al., 2011); or (ii) calcilytics suppress CaSRs in cells of the osteoblast lineage to interfere with PTH-induced cell maturation and key differentiated functions including matrix synthesis and mineralization (Dvorak et al., 2004).

\section{Nutrient Activators of the CaSR}

In addition to its regulation by $\mathrm{Ca}^{2+}$ ions, the CaSR also responds promiscuously to L-amino acids of various classes (Conigrave et al., 2000b), and one of the most potent, L-Trp, has been shown recently to bind in the receptor's VFT domain ligand-binding groove (Geng et al., 2016; see below). This behavior resembles that of several class C GPCRs (Conigrave and Hampson, 2006, 2010) and supports macronutrient sensing in various tissues including the gastrointestinal tract (review: Conigrave and Brown, 2006). Based on the signaling pathway analysis performed to date, however, $\mathrm{Ca}^{2+}{ }_{\mathrm{o}}$ and $\mathrm{L}$-amino acids are not equivalent activators. In particular, L-amino acids preferentially activate a $\mathrm{Ca}^{2+}{ }_{\mathrm{i}}$ mobilizing pathway and have more limited actions on PI-PLC and ERK $1 / 2$ (review: Conigrave and Ward, 2013). Nevertheless, L-amino acids are potent activators of $\mathrm{Ca}^{2+}{ }_{\mathrm{i}}$ mobilization in parathyroid cells and also suppress PTH secretion at physiologically relevant concentrations (Conigrave et al., 2004). Furthermore, glutathione and various analogs (e.g., S-methylglutathione) also activate $\mathrm{Ca}^{2+}{ }_{i}$ mobilization and suppress PTH secretion, presumably by binding to the same VFT domain ligand-binding groove (Broadhead et al., 2011). These findings imply that protein nutritional state is negatively coupled to the control of PTH secretion and thus serum PTH levels. The full significance of these effects, however, is not yet known (see below).

\section{Control of CaSR Gene Expression}

Analysis of the promoter regions of the CaSR gene has led to the identification of two key positive modulators of expression: (i) inflammatory cytokines including IL-1 $\beta$, IL- 6 and TNF $\alpha$ (Canaff and Hendy, 2005); and (ii) hormonally active analogs of vitamin $\mathrm{D}$ including 1,25-dihydroxyvitamin $\mathrm{D}_{3}$ (Canaff and Hendy, 2002), and possibly 25-hydroxyvitamin $\mathrm{D}_{3}$, whose plasma levels are nearly 1000-fold higher. These results suggest that CaSR expression may be upregulated in the parathyroid and other CaSR-expressing tissues in response to various inflammatory conditions and in response to elevations in either serum 1,25dihydroxyvitamin $\mathrm{D}_{3}$ or 25 -hydroxyvitamin $\mathrm{D}_{3}$ levels.

\section{RECENT DEVELOPMENTS AND THE FUTURE}

\section{G-Protein Coupling}

The CaSR couples to various G-proteins (review: Conigrave and Ward, 2013). Notable from the perspective of parathyroid function are $\mathrm{G}_{\mathrm{i}}$, which suppresses agonist-stimulated GPCRmediated cAMP production and contributes to the activation of $\mathrm{ERK}_{1 / 2}$ at least in part via $\beta$-arrestin, and $\mathrm{G}_{\mathrm{q} / 11}$, which activates PI-PLC and induces $\mathrm{Ca}^{2+}{ }_{\mathrm{i}}$ mobilization, with attendant activation of several protein kinase $\mathrm{C}$ isoforms and $\mathrm{ERK}_{1 / 2}$.

Both the $G_{i}$ and $G_{q / 11}$ pathways appear to be important for the inhibitory control of PTH secretion. With respect to $G_{q}$ and $G_{11}$, it is now known that $\mathrm{G} \alpha_{\mathrm{q}}$ and $\mathrm{G} \alpha_{11}$ are required for the normal control of PTH secretion. Thus, in a transgenic mouse in which parathyroid-specific ablation of $\mathrm{G}_{\mathrm{q}}$ was produced on a global $\mathrm{G} \alpha_{11}$ null background, severe neonatal hyperparathyroidism was observed (Wettschureck et al., 2007) and resembled the phenotypes of both global (Ho et al., 1995) and parathyroidspecific (Chang et al., 2008) ablation of the CaSR. These findings demonstrate that $\mathrm{G}_{\mathrm{q}}$ and $\mathrm{G}_{11}$ are required for CaSR-mediated control of PTH secretion and thus lie at the top of a key inhibitory signaling pathway(s). Consistent with these findings, inactivating and activating mutations of the human $\mathrm{G} \alpha_{11}$ gene have been shown respectively to underlie variant forms of $\mathrm{FHH}(\mathrm{FHH} 2)$ and ADH (ADH2; Nesbit et al., 2013a; Gorvin et al., 2016; Piret et al., 2016).

Under certain circumstances, the CaSR also couples to $G_{s}$ (review: Conigrave and Ward, 2013) but the significance of this pathway for the control of PTH secretion is unknown. It is interesting to speculate that the "inactive" form of the receptor, which is promoted under conditions of low $\mathrm{Ca}^{2+}$ and high phosphate concentrations (Geng et al., 2016) might preferentially couple to $\mathrm{G}_{\mathrm{s}}$ in the parathyroid. 


\section{Receptor Trafficking}

Receptor trafficking studies have largely focused on cell systems in which the CaSR is expressed heterologously (reviews: Breitwieser, 2013, 2014). These studies demonstrate that trafficking of the CaSR is modulated by various binding partner proteins (review: Huang and Miller, 2007), can be promoted by allosteric modulators such as cinacalcet and NPS-2143 acting as pharmaco-chaperones (Leach et al., 2013), and is sensitive to receptor-dependent signaling (Grant et al., 2011, 2012; review: Breitwieser, 2012). In the parathyroid, the CaSR interacts with caveolin and is thus likely to localize to sub-domains of the plasma membrane known as caveolae (Kifor et al., 1998). In addition, recent findings suggest that the CaSR is processed between the plasma membrane and intracellular endosomes via clathrin-coated vesicles since mutations of Arg15 of the sigma ( $\sigma$ ) subunit of the clathrin-binding protein AP2 have been linked to a variant form of FHH, now known as FHH3 (Nesbit et al., 2013b). The findings suggest that the formation, and/or maintenance, of CaSR signaling complexes is impaired under conditions in which clathrin-coated vesicle-mediated processing of the CaSR is impaired.

\section{X-ray Crystal Structures}

While X-ray crystal structures of class C GPCR VFT domains (Kunishima et al., 2000; Tsuchiya et al., 2002), entire extracellular (VFT-plus-Cys-rich) domains (Muto et al., 2007), and even heptahelical domains (Doré et al., 2014) have been reported over the last 15 years, crystal structures for CaSR domains have only recently become available (Geng et al., 2016; Zhang et al., 2016).

These newly described CaSR structures provide information on the inactive and active forms of its VFT domain (Geng et al., 2016; Zhang et al., 2016) and entire extracellular domain (Geng et al., 2016). While the protein conformations of the active forms of the VFT domain structures were almost identical, the identification of divalent cation, and anion binding sites were quite different in the structures reported by the two groups. Zhang et al. (2016) identified just one $\mathrm{Ca}^{2+}$ site in the active form of the VFT domain and relied on modeling of electron densities to ascribe it to the ligand-binding cleft, where it was closely associated with an L-amino acid-binding site. Surprisingly, however, they identified a formaldehyde derivative rather than the native form of L-Trp in the site.

In the structures described by Geng et al. (2016), on the other hand, an anomalous mapping strategy was used to identify four, previously unrecognized, $\mathrm{Ca}^{2+}$ binding sites, one of which ("Site 2") was present in both the inactive and active structures and three of which were only identified in the active structure and, thus, may act to stabilize it. Interestingly, no $\mathrm{Ca}^{2+}$ binding site was located in the closed (active) form of the agonistbinding cleft in the structure reported by Geng et al., which was occupied instead by the amino acid L-Trp (Geng et al., 2016). In addition, Geng et al. identified several binding sites for inorganic phosphate in the inactive structure (Geng et al., 2016), raising the possibility that not only the $\mathrm{Ca}^{2+}{ }_{o}$ concentration but also the ratio of $\mathrm{Ca}^{2+}$ o to phosphate concentrations may control the receptor's transition between inactive and active states.

The findings that the receptor binds inorganic phosphate $\left(\mathrm{P}_{\mathrm{i}}\right)$ as well as $\mathrm{Ca}^{2+}$ ions and that $\mathrm{Ca}^{2+}$ stabilizes the active state, whereas $\mathrm{P}_{\mathrm{i}}$ stabilizes the inactive state have potentially important implications for understanding parathyroid function since elevated $\mathrm{P}_{\mathrm{i}}$ concentrations stimulate PTH secretion (Slatopolsky et al., 1996) whereas elevated $\mathrm{Ca}^{2+}$ o inhibits it. Does the CaSR modulate its response to $\mathrm{Ca}^{2+}{ }_{\mathrm{o}}$ according to the background level of inorganic phosphate? Does the $\mathrm{Ca}: \mathrm{P}_{\mathrm{i}}$ ratio determine PTH secretion rates by controlling the activation state of the CaSR? Does the CaSR act as a phosphate sensor in other tissues such as osteocytes or osteoblasts in bone?

\section{Unresolved Problems}

There are several unresolved problems. Four of them are considered below in the form of sets of questions.

\section{Question-Set 1}

What drives intrinsic PTH secretion and how does the CaSR suppress it in a $\mathrm{G}_{\mathrm{i}}$-independent manner? Is spontaneous PTH secretion truly constitutive, implying that the pathway by which PTH vesicles undergo exocytosis is unregulated? Alternatively, is it promoted by receptors expressed on the surface of parathyroid cells that are either constitutively active or exposed to locally released activators such as histamine from mast cells or prostanoids from chief or oxyphil cells?

\section{Question-Set 2}

What is the significance of amino acid-binding to the CaSR (Geng et al., 2016) for parathyroid function? Does the parathyroid CaSR read the local concentrations of $\mathrm{L}$-amino acids arising from export of amino acids from the cytoplasm or are they determined by the amino acid concentrations in the bulk plasma. Does amino acid sensing by the CaSR primarily affect PTH secretion under conditions of protein deficiency and reductions in plasma amino acid levels as suggested by the phenomenon of secondary hyperparathyroidism in subjects on low protein diets (reviews: Conigrave et al., 2002, 2008) or does it act primarily to suppress PTH secretion under conditions of protein excess as suggested by parathyroid cell responses in vitro (Conigrave et al., 2004). Alternatively, might L-amino acid sensing by the CaSR provide a mechanism for adjusting the inhibitory gain on the receptor to the level of amino acid-dependent PTH synthesis?

\section{Question-Set 3}

What is the significance of CaSR heterodimerization for parathyroid function? Is the parathyroid subject solely to control by CaSR homodimers or are some $\mathrm{Ca}^{2+}$-dependent signaling pathways (e.g., for the control of parathyroid chief cell number, or PreProPTH gene expression) subject to control by CaSR heterodimers with metabotropic glutamate receptors (Gama et al., 2001) or $\mathrm{GABA}_{\mathrm{B} 1}$ receptors (Chang et al., 2007)?

\section{Question-Set 4}

Can CaSR expression be effectively upregulated in hypercalcemic conditions such as primary hyperparathyroidism or $\mathrm{FHH}$ to restore physiological control of plasma calcium levels and $\mathrm{Ca}^{2+}{ }_{\mathrm{O}^{-}}$ dependent suppression of PTH secretion? Can CaSR expression be effectively downregulated in hypocalcemic conditions such as $\mathrm{ADH}$ to restore physiological control of plasma calcium and $\mathrm{PTH}$ levels? Can tissue-selective modulators of the vitamin $\mathrm{D}$ receptor 
or cytokine receptors, or other strategies, be developed for the control of parathyroid CaSR expression?

\section{CONCLUDING REMARKS}

The role of the parathyroid in the whole body calcium economy is so important that the negative feedback loop by which PTH elevates plasma $\mathrm{Ca}^{2+}$ and $\mathrm{Ca}^{2+}$, in turn, suppresses PTH secretion largely defines its place in human biology. Expression cloning of the CaSR, its identification as the key $\mathrm{Ca}^{2+}$ sensor of the parathyroid, and evaluation of its roles in normal tissue biology and in human disease have resolved key issues in calcium metabolism. New paradigms of $\mathrm{Ca}^{2+}$-mediated control of tissue function and of the CaSR in macronutrientsensing have followed. Incredibly, the molecular mechanism by which the CaSR suppresses PTH secretion is only partially solved: for the situation in which PTH secretion is stimulated by neurotransmitters or hormones that elevate cAMP levels. The mechanisms by which the CaSR suppresses intrinsic PTH secretion or the secretion of PTH downstream of hormones that activate PTH secretion by non-cAMP pathways remain undefined. Newly available X-ray crystal structures for the CaSR extracellular domain in its inactive and active conformations provide new opportunities to investigate the $\mathrm{Ca}^{2+}$ sensing mechanism.

\section{REFERENCES}

Alexander, S., Hunter, T., Walter, S., Dong, J., Maclean, D., Baruch, A., et al. (2015). Critical Cysteine residues in both the calcium-sensing receptor and the allosteric activator AMG 416 underlie the mechanism of action. Mol. Pharmacol. 88, 853-865. doi: 10.1124/mol.115.098392

Ba, J., Brown, D., and Friedman, P. A. (2003). Calcium-sensing receptor regulation of PTH-inhibitable proximal tubule phosphate transport. Am. J. Physiol. 285, F1233-F1243. doi: 10.1152/ajprenal.00249.2003

Bai, M., Trivedi, S., and Brown, E. M. (1998). Dimerization of the extracellular calcium-sensing receptor $(\mathrm{CaR})$ on the cell surface of CaR-transfected HEK293 cells. J. Biol. Chem. 273, 23605-23610. doi: 10.1074/jbc.273.36.23605

Bai, M., Trivedi, S., Kifor, O., Quinn, S. J., and Brown, E. M. (1999). Intermolecular interactions between dimeric calcium-sensing receptor monomers are important for its normal function. Proc. Natl. Acad. Sci. U.S.A. 96, 2834-2839. doi: $10.1073 /$ pnas.96.6.2834

Bell, G., Huang, S., Martin, K. J., and Block, G. A. (2015). A randomized, doubleblind, phase 2 study evaluating the safety and efficacy of AMG 416 for the treatment of secondary hyperparathyroidism in hemodialysis patients. Curr. Med. Res. Opin. 31, 943-952. doi: 10.1185/03007995.2015.1031731

Birnbaumer, M. E., Schneider, A. B., Palmer, D., Hanley, D. A., and Sherwood, L. M. (1977). Secretion of parathyroid hormone by abnormal human parathyroid glands in vitro. J. Clin. Endocrinol. Metab. 45, 105-113. doi: 10.1210/jcem-45-1-105

Breitwieser, G. (2012). Minireview: the intimate link between calcium sensing receptor trafficking and signaling: implications for disorders of calcium homeostasis. Mol. Endocrinol. 26, 1482-1495. doi: 10.1210/me.2011-1370

Breitwieser, G. (2013). The calcium sensing receptor life cycle: trafficking, cell surface expression, and degradation. Best Pract. Res. Clin. Endocrinol. Metab. 27, 303-313. doi: 10.1016/j.beem.2013.03.003

Breitwieser, G. (2014). Pharmacoperones and the calcium sensing receptor: exogenous and endogenous regulators. Pharmacol. Res. 83, 30-37. doi: 10.1016/j.phrs.2013.11.006

Broadhead, G. K., Mun, H. C., Avlani, V. A., Jourdon, O., Church, W. B., Christopoulos, A., et al. (2011). Allosteric modulation of the calcium-sensing

\section{AUTHOR CONTRIBUTIONS}

The author confirms being the sole contributor of this work and approved it for publication.

\section{FUNDING}

The author's work on the role of the calcium-sensing receptor has been funded by the National Health \& Medical Research Council of Australia (project grants APP1011922, APP1026962, and APP1085143).

\section{ACKNOWLEDGMENTS}

The author thanks Dr. Dorothea Szczawinska and Dr. Heechang Mun for the opportunity to discuss several of the issues relating to parathyroid biology that are considered in this manuscript. He also thanks his current collaborators in the field of calcium-sensing receptor biology including Dr. Donald Ward of the University of Manchester, England UK, Prof Arthur Christopoulos, and Dr. Katie Leach of the Monash Institute of Pharmaceutical Sciences, Parkville, Victoria, Australia, and in the field of parathyroid biology, Profs. Leigh Delbridge and Stan Sidhu of the Department of Surgery, Royal North Shore Hospital, St. Leonards, NSW, Australia.

receptor by, $\gamma$-glutamyl peptides: inhibition of PTH secretion, suppression of intracellular cAMP levels and a common mechanism of action with L-amino acids. J. Biol. Chem. 286, 8786-8797. doi: 10.1074/jbc.M110. 149724

Brown, E. (2009). Anti-parathyroid and anti-calcium sensing receptor antibodies in autoimmune hypoparathyroidism. Endocrinol. Metab. Clin. North Am. 38, 437-445. doi: 10.1016/j.ecl.2009.01.001

Brown, E. M., Gardner, D. G., Brennan, M. F., Marx, S. J., Spiegel, A. M., Attie, M. F., et al. (1979a). Calcium-regulated parathyroid hormone release in primary hyperparathyroidism: studies in vitro with dispersed parathyroid cells. Am. J. Med. 66, 923-931. doi: 10.1016/0002-9343(79)90446-7

Brown, E. M., Gardner, D. G., Windeck, R. A., Hurwitz, S., Brennan, M. F., and Aurbach, G. D. (1979b). Beta-adrenergically stimulated adenosine $3^{\prime}, 5^{\prime}$ monophosphate accumulation in and parathyroid hormone release from dispersed human parathyroid cells. J. Clin. Endocrinol. Metab. 48, 618-626. doi: 10.1210/jcem-48-4-618

Brown, E. M., Hurwitz, S., and Aurbach, G. D. (1976). Preparation of viable isolated bovine parathyroid cells. Endocrinology 99, 1582-1588. doi: 10.1210/endo-99-6-1582

Brown, E. M., Hurwitz, S., and Aurbach, G. D. (1977a). Beta-adrenergic stimulation of cyclic AMP content and parathyroid hormone release from isolated bovine parathyroid cells. Endocrinology 100, 1696-1702. doi: 10.1210/endo-100-6-1696

Brown, E. M., Brennan, M. F., Hurwitz, S., Windeck, R., Marx, S. J., Spiegel, A. M., et al. (1978a). Dispersed cells prepared from human parathyroid glands: distinct calcium sensitivity of adenomas vs. primary hyperplasia. J. Clin. Endocrinol. Metab. 46, 267-275. doi: 10.1210/jcem-46-2-267

Brown, E. M., Broadus, A. E., Brennan, M. F., Gardner, D. G., Marx, S. J., Spiegel, A. M., et al. (1979c). Direct comparison in vivo and in vitro of suppressibility of parathyroid function by calcium in primary hyperparathyroidism. J. Clin. Endocrinol. Metab. 48, 604-610. doi: 10.1210/jcem-48-4-604

Brown, E. M., Butters, R., Katz, C., and Kifor, O. (1991b). Neomycin mimics the effects of high extracellular calcium concentrations on parathyroid function in dispersed bovine parathyroid cells. Endocrinology (Baltimore) 128, 3047-3054. doi: 10.1210/endo-128-6-3047 
Brown, E. M., Butters, R., Katz, C., Kifor, O., and Fuleihan, G. E. (1992). A comparison of the effects of concanavalin-A and tetradecanoylphorbol acetate on the modulation of parathyroid function by extracellular calcium and neomycin in dispersed bovine parathyroid cells. Endocrinology 130, 3143-3151.

Brown, E. M., Carroll, R. J., and Aurbach, G. D. (1977b). Dopaminergic stimulation of cyclic AMP accumulation and parathyroid hormone release from dispersed bovine parathyroid cells. Proc. Natl. Acad. Sci. U.S.A. 74, 4210-4213. doi: 10.1073/pnas.74.10.4210

Brown, E. M., Enyedi, P., Leboff, M., Rotberg, J., Preston, J., and Chen, C. (1987). High extracellular $\mathrm{Ca}^{2+}$ and $\mathrm{Mg}^{2+}$ stimulate accumulation of inositol phosphates in bovine parathyroid cells. FEBS Lett. 218, 113-118. doi: 10.1016/0014-5793(87)81029-3

Brown, E. M., Fuleihan, G. E., Chen, C. J., and Kifor, O. (1990). A comparison of the effects of divalent and trivalent cations on parathyroid hormone release, $3^{\prime}, 5^{\prime}$-cyclic-adenosine monophosphate accumulation, and the levels of inositol phosphates in bovine parathyroid cells. Endocrinology 127, 1064-1071. doi: 10.1210/endo-127-3-1064

Brown, E. M., Gamba, G., Riccardi, D., Lombardi, M., Butters, R., Kifor, O., et al. (1993). Cloning and characterization of an extracellular $\mathrm{Ca}^{2+}$-sensing receptor from bovine parathyroid. Nature 366, 575-580. doi: 10.1038/366575a0

Brown, E. M., Gardner, D. G., Windeck, R. A., and Aurbach, G. D. (1978b). Relationship of intracellular $3^{\prime}, 5^{\prime}$-monophosphate accumulation to parathyroid hormone release from dispersed bovine parathyroid cells. Endocrinology 103, 2323-2333. doi: 10.1210/endo-103-6-2323

Brown, E. M., Katz, C., Butters, R., and Kifor, O. (1991a). Polyarginine, polylysine, and protamine mimic the effects of high extracellular calcium concentrations on dispersed bovine parathyroid cells. J. Bone Miner. Res. 6, 1217-1225. doi: $10.1002 /$ jbmr.5650061112

Brown, E. M., Leombruno, R., Thatcher, J., and Burrowes, M. (1985). The acute secretory response to alterations in extracellular calcium concentration and dopamine in perifused bovine parathyroid cells. Endocrinology 116, 1123-1132. doi: 10.1210/endo-116-3-1123

Brown, E. M., and MacLeod, R. J. (2001). Extracellular calcium sensing and extracellular calcium signaling. Physiol. Rev. 81, 239-297.

Brown, E. M., Pollak, M., Seidman, C. E., Seidman, J. G., Chou, Y. H., Riccardi, D., et al. (1995). Calcium-ion-sensing cell-surface receptors. N. Engl. J. Med. 333, 234-240. doi: 10.1056/NEJM199507273330407

Canaff, L., and Hendy, G. (2005). Calcium-sensing receptor gene transcription is up-regulated by the proinflammatory cytokine, interleukin-1beta. Role of the NF-kappaB PATHWAY and kappaB elements. J. Biol. Chem. 280, 14177-14188. doi: $10.1074 /$ jbc.M408587200

Canaff, L., and Hendy, G. N. (2002). Human calcium-sensing receptor gene. Vitamin D response elements in promoters P1 and P2 confer transcriptional responsiveness to 1,25-dihydroxyvitamin D. J. Biol. Chem. 277, 30337-30350. doi: 10.1074/jbc.M201804200

Chang, W., Tu, C., Chen, T. H., Bikle, D., and Shoback, D. (2008). The extracellular calcium-sensing receptor (CaSR) is a critical modulator of skeletal development. Sci. Signal. 1, ra1. doi: 10.1126/scisignal.1159945

Chang, W., Tu, C., Cheng, Z., Rodriguez, L., Chen, T. H., Gassmann, M., et al. (2007). Complex formation with the Type B gamma-aminobutyric acid receptor affects the expression and signal transduction of the extracellular calcium-sensing receptor. Studies with HEK-293 cells and neurons. J. Biol. Chem. 282, 25030-25040. doi: 10.1074/jbc.M700924200

Chen, C. J., Barnett, J. V., Congo, D. A., and Brown, E. M. (1989). Divalent cations suppress $3^{\prime}, 5^{\prime}$-adenosine monophosphate accumulation by stimulating a pertussis toxin sensitive guanine nucleotide-binding protein in cultured bovine parathyroid cells. Endocrinology 124, 233-239. doi: 10.1210/endo-124-1-233

Chen, C. J., and Brown, E. M. (1990). The diltiazem analog TA-3090 mimics the actions of high extracellular $\mathrm{Ca}^{2+}$ on parathyroid function in dispersed bovine parathyroid cells. J. Bone Miner. Res. 5, 581-587. doi: 10.1002/jbmr.56500 50607

Cheng, Z., Tu, C., Rodriguez, L., Chen, T. H., Dvorak, M. M., Margeta, M., et al. (2007). Type B gamma-aminobutyric acid receptors modulate the function of the extracellular $\mathrm{Ca}^{2+}$-sensing receptor and cell differentiation in murine growth plate chondrocytes. Endocrinology 148, 4984-4992. doi: 10.1210/en.2007-0653

Christiansen, B., Hansen, K., Wellendorph, P., and Bräuner-Osborne, H. (2007). Pharmacological characterization of mouse GPRC6A an, L- and alpha-amino-acid receptor modulated by divalent cations. $\mathrm{Br}$. J. Pharmacol. 150, 798-807. doi: 10.1038/sj.bjp.0707121

Chu, Y. W., Pollak, M. R., Brandi, M. L., Toss, G., Arnqvist, H., Atkinson, A. B., et al. (1995). Mutations in the human $\mathrm{Ca}^{2+}$-sensing receptor gene that cause familial hypocalciuric hypercalcemia. Am. J. Hum. Genet. 56, 1075-1079.

Colloton, M., Shatzen, E., Miller, G., Stehman-Breen, C., Wada, M., Lacey, D., et al. (2005). Cinacalcet $\mathrm{HCl}$ attenuates parathyroid hyperplasia in a rat model of secondary hyperparathyroidism. Kidney Int. 67, 467-476. doi: 10.1111/j.1523-1755.2005.67103.x

Conigrave, A. D., and Ward, D. T. (2013). Calcium-sensing receptor (CaSR): pharmacological properties and signaling pathways. Best Pract. Res. Clin. Endocrinol. Metab. 27, 315-331. doi: 10.1016/j.beem.2013.05.010

Conigrave, A. D., and Brown, E. M. (2006). L-amino acid-sensing by calciumsensing receptors: implications for GI physiology. Am. J. Physiol. 291, G753G761.

Conigrave, A. D., Brown, E. M., and Rizzoli, R. (2008). Dietary protein and bone health: roles of amino acid-sensing receptors in the control of calcium metabolism and bone homeostasis. Annu. Rev. Nutr. 28, 131-155. doi: 10.1146/annurev.nutr.28.061807.155328

Conigrave, A. D., Franks, A. H., Brown, E. M., and Quinn, S. J. (2002). LAmino acid sensing by the calcium-sensing receptor: a general mechanism for coupling protein and calcium metabolism? Eur. J. Clin. Nutr. 56, 1072-1080. doi: $10.1038 /$ sj.ejcn. 1601463

Conigrave, A. D., and Hampson, D. R. (2006). Broad-spectrum amino acid sensing by class 3 G-protein coupled receptors. Trends Endocrinol. Metab. 17, 398-407. doi: 10.1016/j.tem.2006.10.012

Conigrave, A. D., and Hampson, D. R. (2010). Broad-spectrum amino acid-sensing class C G-protein coupled receptors: molecular mechanisms, physiological significance and options for drug development. Pharmacol. Ther. 127, 252-260. doi: 10.1016/j.pharmthera.2010.04.007

Conigrave, A. D., Quinn, S. J., and Brown, E. M. (2000a). Cooperative multimodal sensing and therapeutic implications of the extracellular $\mathrm{Ca}^{2+}$-sensing receptor. Trends Pharm. Sci. 21, 401-407. doi: 10.1016/S0165-6147(00)01546-7

Conigrave, A. D., Quinn, S. J., and Brown, E. M. (2000b). L-amino acid sensing by the extracellular $\mathrm{Ca}^{2+}$-sensing receptor. Proc. Natl. Acad. Sci. U.S.A. 97, 4814-4819. doi: 10.1073/pnas.97.9.4814

Conigrave, A. D., Mun, H. C., Delbridge, L., Quinn, S. J., Wilkinson, M., and Brown, E. M. (2004). L-amino acids regulate parathyroid hormone secretion. J. Biol. Chem. 279, 38151-38159. doi: 10.1074/jbc.M406373200

Conlin, P. R., Fajtova, V. T., Mortensen, R. M., LeBoff, M. S., and Brown, E. M. (1989). Hysteresis in the relationship between serum ionized calcium and intact parathyroid hormone during recovery from induced hyper- and hypocalcemia in normal humans. J. Clin. Endocrinol. Metab. 69, 593-599. doi: 10.1210/jcem-69-3-593

Corbetta, S., Lania, A., Filopanti, M., Vicentini, L., Ballaré, E., and Spada, A. (2002). Mitogen-activated protein kinase cascade in human normal and tumoral parathyroid cells. J. Clin. Endocrinol. Metab. 87, 2201-2205. doi: 10.1210/jcem.87.5.8492

Daly, K., Al-Rammahi, M., Moran, A., Marcello, M., Ninomiya, Y., and ShiraziBeechey, S. P. (2013). Sensing of amino acids by the gut-expressed taste receptor T1R1-T1R3 stimulates CCK secretion. Am. J. Physiol. Gastrointest Liver Physiol. 304, G271-G282. doi: 10.1152/ajpgi.00074.2012

Davey, A. E., Leach, K., Valant, C., Conigrave, A. D., Sexton, P. M., and Christopoulos, A. (2012). Positive and negative allosteric modulators promote biased signaling at the calcium-sensing receptor. Endocrinology 153, 1232-1241. doi: 10.1210/en.2011-1426

Davies, S. L., Ozawa, A., McCormick, W. D., Dvorak, M. M., and Ward, D. T. (2007). Protein kinase C-mediated phosphorylation of the calciumsensing receptor is stimulated by receptor activation and attenuated by calyculin-sensitive phosphatase activity. J. Biol. Chem. 282, 15048-15056. doi: 10.1074/jbc.M607469200

Doré, A. S., Okrasa, K., Patel, J. C., Serrano-Vega, M., Bennett, K., Cooke, R. M., et al. (2014). Structure of class C GPCR metabotropic glutamate receptor 5 transmembrane domain. Nature 511, 557-562. doi: 10.1038/nature13396

Dvorak, M. M., Siddiqua, A., Ward, D. T., Carter, D. H., Dallas, S. L., Nemeth, E. F., et al. (2004). Physiological changes in extracellular calcium concentration directly control osteoblast function in the absence of calciotropic hormones. Proc. Natl. Acad. Sci. U.S.A. 101, 5140-5145. doi: 10.1073/pnas.0306141101 
Egbuna, O. I., and Brown, E. M. (2008). Hypercalcaemic and hypocalcaemic conditions due to calcium-sensing receptor mutations. Best Pract. Res. Clin. Rheumatol. 22, 129-148. doi: 10.1016/j.berh.2007.11.006

Fitzpatrick, L. A., Brandi, M. L., and Aurbach, G. D. (1986a). Calciumcontrolled secretion is effected through a guanine nucleotide regulatory protein in parathyroid cells. Endocrinology 119, 2700-2703. doi: 10.1210/endo-119-6-2700

Fitzpatrick, L. A., Brandi, M. L., and Aurbach, G. D. (1986b). Control of PTH secretion is mediated through calcium channels and is blocked by pertussis toxin treatment of parathyroid cells. Biochem. Biophys. Res. Commun. 138, 960-965. doi: 10.1016/S0006-291X(86)80589-7

Fitzpatrick, L. A., Chin, H., Nirenberg, M., and Aurbach, G. D. (1988). Antibodies to an a-subunit of skeletal muscle calcium channels regulate parathyroid secretion. Proc. Natl. Acad. Sci. U.S.A. 85, 2115-2119. doi: 10.1073/pnas.85.7.2115

Fitzpatrick, L. A., Yasumoto, T., and Aurbach, G. D. (1989). Inhibition of parathyroid hormone release by maitotoxin, a calcium channel activator. Endocrinology 124, 97-103. doi: 10.1210/endo-124-1-97

Fox, J., and Heath, H. (1981). The "calcium clamp": effect of constant hypocalcemia on parathyroid hormone secretion. Am. J. Physiol. 240, E649-E655.

Gama, L., Wilt, S. G., and Breitwieser, G. E. (2001). Heterodimerization of calcium sensing receptors with metabotropic glutamate receptors in neurons. J. Biol. Chem. 276, 39053-39059. doi: 10.1074/jbc.M105662200

Gamba, G., and Friedman, P. A. (2009). Thick ascending limb: the $\mathrm{Na}^{+}: \mathrm{K}^{+}: 2 \mathrm{Cl}^{-}$ co-transporter, NKCC2, and the calcium-sensing receptor. Pflugers Arch. 458, 61-76. doi: 10.1007/s00424-008-0607-1

Gardner, D. G., Brown, E. M., Attie, M. F., and Aurbach, G. D. (1980). Prostaglandin-mediated stimulation of adenosine $3^{\prime}, 5^{\prime}$ monophosphate accumulation and parathyroid hormone release in dispersed human parathyroid cells. J. Clin. Endocrinol. Metab. 51, 20-25. doi: 10.1210/jcem-51-1-20

Garrett, J. E., Capuano, I. V., Hammerland, L. J., Hung, B. C. P., Brown, E. M., Hebert, S. C., et al. (1995). Molecular cloning and functional expression of human parathyroid calcium receptor cDNAs. J. Biol. Chem. 270, 12919-12925. doi: $10.1074 /$ jbc.270.21.12919

Geng, Y., Mosyak, L., Kurinov, I., Zuo, H., Sturchler, E., Cheng, T., et al. (2016). Structural mechanism of ligand activation in human calcium-sensing receptor. Elife 5:e13662. doi: 10.7554/eLife.13662

Goltzman, D., and Hendy, G. (2015). The calcium-sensing receptor in bonemechanistic and therapeutic insights. Nat. Rev. Endocrinol. 11, 298-307. doi: $10.1038 /$ nrendo. 2015.30

Gorvin, C. M., Cranston, T., Hannan, F. M., Rust, N., Qureshi, A., Nesbit, M. A., et al. (2016). A G-protein Subunit- $\alpha 11$ Loss-of-Function Mutation, Thr54Met, Causes Familial Hypocalciuric Hypercalcemia Type 2 (FHH2). J. Bone Miner. Res. 31, 1200-1206. doi: 10.1002/jbmr.2778

Grant, M. P., Stepanchick, A., and Breitwieser, G. E. (2012). Calcium signaling regulates trafficking of familial hypocalciuric hypercalcemia $(\mathrm{FHH})$ mutants of the calcium sensing receptor. Mol. Endocrinol. 26, 2081-2091. doi: $10.1210 /$ me.2012-1232

Grant, M. P., Stepanchick, A., Cavanaugh, A., and Breitwieser, G. E. (2011). Agonist-driven maturation and plasma membrane insertion of calciumsensing receptors dynamically control signal amplitude. Sci. Signal. 4, ra78. doi: 10.1126/scisignal.2002208

Hendy, G. N., D’Souza-Li, L., Yang, B., Canaff, L., and Cole, D. E. (2000). Mutations of the calcium-sensing receptor (CASR) in familial hypocalciuric hypercalcemia, neonatal severe hyperparathyroidism, and autosomal dominant hypocalcemia. Hum. Mutat. 16, 281-296. doi: 10.1002/1098-1004(200010)16:4<281::AID-HUMU1>3.0.CO;2-A

Ho, C., Conner, D. A., Pollak, M. R., Ladd, D. J., Kifor, O., Warren, H. B., et al. (1995). A mouse model of human familial hypocalciuric hypercalcemia and neonatal severe hyperparathyroidism. Nat. Genet. 11, 389-394. doi: 10.1038/ng1295-389

Hough, T. A., Bogani, D., Cheeseman, M. T., Favor, J., Nesbit, M. A., Thakker, R. V., et al. (2004). Activating calcium-sensing receptor mutation in the mouse is associated with cataracts and ectopic calcification. Proc. Natl. Acad. Sci. U.S.A. 101, 13566-13571. doi: 10.1073/pnas.04055 16101
Huang, C., and Miller, R. T. (2007). The calcium-sensing receptor and its interacting proteins. J. Cell. Mol. Med. 11, 923-934. doi: 10.1111/j.1582-4934.2007.00114.x

Imanishi, Y., Kawata, T., Kenko, T., Wada, M., Nagano, N., Miki, T., et al. (2011). Cinacalcet $\mathrm{HCl}$ suppresses Cyclin D1 oncogene-derived parathyroid cell proliferation in a murine model for primary hyperparathyroidism. Calcif. Tissue Int. 89, 29-35. doi: 10.1007/s00223-011-9490-4

Jiang, Y. F., Zhang, Z., Kifor, O., Lane, C. R., Quinn, S. J., and Bai, M. (2002). Protein kinase C (PKC) phosphorylation of the $\mathrm{Ca}^{2+}{ }_{\mathrm{o}}$-sensing receptor $(\mathrm{CaR})$ modulates functional interaction of $\mathrm{G}$ proteins with the $\mathrm{CaR}$ cytoplasmic tail. J. Biol. Chem. 277, 50543-50549. doi: 10.1074/jbc.M205798200

Kantham, L., Quinn, S. J., Egbuna, O. I., Baxi, K., Butters, R., Pang, J. L., et al. (2009). The calcium-sensing receptor (CaSR) defends against hypercalcemia independently of its regulation of parathyroid hormone secretion. Am. J. Physiol. Endocrinol. Metab. 297, E915-E923. doi: 10.1152/ajpendo.00315.2009

Kemp, E. H., Gavalas, N. G., Akhtar, S., Krohn, K. J., Pallais, J. C., Brown, E. M., et al. (2010). Mapping of human autoantibody binding sites on the calciumsensing receptor. J. Bone Miner. Res. 25, 132-140. doi: 10.1359/jbmr.090703

Kifor, O., Diaz, R., Butters, R., Kifor, I., and Brown, E. M. (1998). The calcium-sensing receptor is localized in caveolin-rich plasma membrane domains of bovine parathyroid cells. J. Biol. Chem. 273, 21708-21713. doi: $10.1074 /$ jbc.273.34.21708

Kifor, O., MacLeod, R. J., Diaz, R., Bai, M., Yamaguchi, T., Yao, T., et al. (2001). Regulation of MAP kinase by calcium-sensing receptor in bovine parathyroid and CaR-transfected HEK293 cells. Am. J. Physiol. Renal Physiol. 280, F291F302.

Kifor, O., Moore, F. D. Jr., Delaney, M., Garber, J., Hendy, G. N., Butters, R., et al. (2003). A syndrome of hypocalciuric hypercalcemia caused by autoantibodies directed at the calcium-sensing receptor. J. Clin. Endocrinol. Metab. 88, 60-72. doi: $10.1210 /$ jc.2002-020249

Kimura, S., Nakagawa, T., Matsuo, Y., Ishida, Y., Okamoto, Y., and Hayashi, M. (2011). JTT-305, an orally active calcium-sensing receptor antagonist, stimulates transient parathyroid hormone release and bone formation in ovariectomized rats. Eur. J. Pharmacol. 668, 331-336. doi: 10.1016/j.ejphar.2011.07.015

Kubo, Y., Miyashita, T., and Murata, Y. (1998). Structural basis for a $\mathrm{Ca}^{2+}$-sensing function of the metabotropic glutamate receptors. Science 279, 1722-1725. doi: 10.1126/science.279.5357.1722

Kunishima, N., Shimada, Y., Tsuji, Y., Sato, T., Yamamoto, M., Kumasaka, T., et al. (2000). Structural basis of glutamate recognition by a dimeric metabotropic glutamate receptor. Nature 407, 971-977. doi: 10.1038/35039564

Lazarus, S., Pretorius, C. J., Khafagi, F., Campion, K. L., Brennan, S. C., Conigrave, A. D., et al. (2011). A novel mutation of the primary protein kinase $\mathrm{C}$ phosphorylation site in the calcium-sensing receptor causes autosomal dominant hypocalcemia. Eur. J. Endocrinol. 164, 429-435. doi: 10.1530/EJE-10-0907

Leach, K., Conigrave, A. D., Sexton, P. M., and Christopoulos, A. (2015). Towards tissue-specific pharmacology: insights from the calcium-sensing receptor as a paradigm for GPCR (patho)physiological bias. Trends Pharmacol. Sci. 36, 215-225. doi: 10.1016/j.tips.2015.02.004

Leach, K., Gregory, K. J., Kufareva, I., Khajehali, E., Cook, A. E., Abagyan, R., et al. (2016). Towards a structural understanding of allosteric drugs at the human calcium-sensing receptor. Cell Res. 26, 574-592. doi: 10.1038/cr.2016.36

Leach, K., Wen, A., Cook, A. E., Sexton, P. M., Conigrave, A. D., and Christopoulos, A. (2013). Impact of clinically relevant mutations on the pharmacoregulation and signaling bias of the calcium-sensing receptor by positive and negative allosteric modulators. Endocrinology 154, 1105-1116. doi: 10.1210/en.2012-1887

Loupy, A., Ramakrishnan, S. K., Wootla, B., Chambrey, R., de la Faille, R., Bourgeois, S., et al. (2012). PTH-independent regulation of blood calcium concentration by the calcium-sensing receptor. J. Clin. Invest. 122, 3355-3367. doi: 10.1172/JCI57407

MacCallum, W. G., Lambert, R. A., and Vogel, K. M. (1914). The removal of calcium from the blood by dialysis in the study of tetany. J. Exp. Med. 20, 149-168. doi: 10.1084/jem.20.2.149

MacCallum, W. G., and Voegtlin, C. (1909). On the relation of tetany to the parathyroid glands and to calcium metabolism. J. Exp. Med. 11, 118-151. doi: $10.1084 /$ jem.11.1.118 
Marx, S. J., Lasker, R. D., Brown, E. M., Fitzpatrick, L. A., Sweezey, N. B., Goldbloom, R. B., et al. (1986). Secretory dysfunction in parathyroid cells from a neonate with severe primary hyperparathyroidism. J. Clin. Endocrinol. Metab. 62, 445-449. doi: 10.1210/jcem-62-2-445

Mayr, B., Glaudo, M., and Schöfl, C. (2016). Activating calcium-sensing receptor mutations: prospects for future treatment with calcilytics. Trends Endocrinol. Metab. 27, 643-652. doi: 10.1016/j.tem.2016.05.005

Messa, P., Alfieri, C., and Brezzi, B. (2008). Cinacalcet: pharmacological and clinical aspects. Expert Opin. Drug Metab. Toxicol. 4, 1551-1560. doi: $10.1517 / 17425250802587017$

Miller, G., Davis, J., Shatzen, E., Colloton, M., Martin, D., and Henley, C. M. (2012). Cinacalcet $\mathrm{HCl}$ prevents development of parathyroid gland hyperplasia and reverses established parathyroid gland hyperplasia in a rodent model of CKD. Nephrol. Dial. Transplant. 27, 2198-2205. doi: 10.1093/ndt/gfr589

Moe, S. M., Cunningham, J., Bommer, J., Adler, S., Rosansky, S. J., Urena-Torres, P., et al. (2005). Long-term treatment of secondary hyperparathyroidism with the calcimimetic cinacalcet HCl. Nephrology Dialysis Transplant. 20, 2186-2193. doi: 10.1093/ndt/gfh966

Morrissey, J. J., and Cohn, D. V. (1978). The effects of calcium and magnesium on the secretion of parathormone and parathyroid secretory protein by isolated porcine parathyroid cells. Endocrinology 103, 2081-2090. doi: 10.1210/endo-103-6-2081

Mun, H. C., Brennan, S. C., Delbridge, L., Wilkinson, M., Brown, E. M., and Conigrave, A. D. (2009). Adenomatous human parathyroid cells exhibit impaired sensitivity to L-amino acids. J. Clin. Endocrinol. Metab. 94, 3567-3574. doi: 10.1210/jc.2008-2714

Muto, T., Tsuchiya, D., Morikawa, K., and Jingami, H. (2007). Structures of the extracellular regions of the group II/III metabotropic glutamate receptors. Proc. Natl. Acad. Sci. U.S.A. 104, 3759-3764. doi: 10.1073/pnas.0611577104

Nemeth, E. F., and Goodman, W. G. (2016). Calcimimetic and calcilytic drugs: feats, flops, and futures. Calcif. Tissue Int. 98, 341-358. doi: 10.1007/s00223-015-0052-Z

Nemeth, E. F., Heaton, W. H., Miller, M., Fox, J., Balandrin, M. F., Van Wagenen, B. C., et al. (2004). Pharmacodynamics of the type II calcimimetic compound cinacalcet HCl. J. Pharmacol. Exp. Ther. 308, 627-635. doi: 10.1124/jpet.103.057273

Nemeth, E. F. (2006). Misconceptions about calcimimetics. Ann. N.Y Acad. Sci. 1068, 471-476. doi: 10.1196/annals.1346.044

Nemeth, E. F., Delmar, E. G., Heaton, W. L., Miller, M. A., Lambert, L. D., Conklin, R. L., et al. (2001). Calcilytic compounds: potent and selective $\mathrm{Ca}^{2+}$ receptor antagonists that stimulate secretion of parathyroid hormone. J. Pharmacol. Exp. Ther. 299, 323-331.

Nemeth, E. F., and Scarpa, A. (1986). Cytosolic $\mathrm{Ca}^{2+}$ and the regulation of secretion in parathyroid cells. FEBS Lett. 203, 15-19. doi: 10.1016/0014-5793(86)81427-2

Nemeth, E. F., and Scarpa, A. (1987a). Rapid mobilization of cellular $\mathrm{Ca}^{2+}$ in bovine parathyroid cells evoked by extracellular divalent cations. Evidence for a cell surface calcium receptor. J. Biol. Chem. 262, 5188-5196.

Nemeth, E. F., and Scarpa, A. (1987b). "Spermine evokes the rapid mobilization of cellular $\mathrm{Ca}^{2+}$ in parathyroid cells," in Calcium-Binding Proteins in Health and Disease, eds A. W. Norman, T. C. Vanaman, and A. R. Means (San Diego, CA: Academic Press), 33-35.

Nemeth, E. F., and Shoback, D. (2013). Calcimimetic and calcilytic drugs. Best Pract. Res. Clin. Endocrinol. Metab. 27, 373-384. doi: 10.1016/j.beem.2013.02.008

Nemeth, E. F., Steffey, M. E., Hammerland, L. G., Hung, B. C. P., van Wagenen, B. C., Delmar, E. G., et al. (1998). Calcimimetics with potent and selective activity on the parathyroid calcium receptor. Proc. Natl. Acad. Sci. U.S.A. 95, 4040-4045. doi: 10.1073/pnas.95.7.4040

Nesbit, M. A., Hannan, F. M., Howles, S. A., Babinsky, V. N., Head, R. A., Cranston, T., et al. (2013a). Mutations affecting G-protein subunit a11 in hypercalcemia and hypocalcemia. N.Engl. J. Med. 368, 2476-2486. doi: 10.1056/NEJMoa1300253

Nesbit, M. A., Hannan, F. M., Howles, S. A., Reed, A. A., Cranston, T., Thakker, C. E., et al. (2013b). Mutations in AP2S1 cause familial hypocalciuric hypercalcemia type 3. Nat. Genet. 45, 93-97. doi: 10.1038/ng. 2492
Pallais, J. C., Kifor, O., Chen, Y. B., Slovik, D., and Brown, E. M. (2004). Acquired hypocalciuric hypercalcemia due to autoantibodies against the calcium-sensing receptor. N. Engl. J. Med. 351, 362-369. doi: 10.1056/NEJMoa040008

Parisi, E., Almadén, Y., Ibarz, M., Panizo, S., Cardús, A., Rodriguez, M., et al. (2009). N-methyl-D-aspartate receptors are expressed in rat parathyroid gland and regulate PTH secretion. Am. J. Physiol. Renal Physiol. 296, F1291-F1296. doi: 10.1152/ajprenal.90557.2008

Peacock, M., Bilezikian, J. P., Bolognese, M. A., Borofsky, M., Scumpia, S., Sterling, L. R., et al. (2011). Cinacalcet $\mathrm{HCl}$ reduces hypercalcemia in primary hyperparathyroidism across a wide spectrum of disease severity. J. Clin. Endocrinol. Metab. 96, E9-E18. doi: 10.1210/jc.2010-1221

Peacock, M., Bilezikian, J. P., Klassen, P. S., Guo, M. D., Turner, S. A., and Shoback, D. (2005). Cinacalcet hydrochloride maintains long-term normocalcemia in patients with primary hyperparathyroidism. J. Clin. Endocrinol. Metab. 90, 135-141. doi: 10.1210/jc.2004-0842

Pearce, S. H., Williamson, C., Kifor, O., Bai, M., Coulthard, M. G., Davies, M., et al. (1996). A familial syndrome of hypocalcemia with hypercalciuria due to mutations in the calcium-sensing receptor. N. Engl. J. Med. 335, 1115-1122. doi: 10.1056/NEJM199610103351505

Piret, S. E., Gorvin, C. M., Pagnamenta, A. T., Howles, S. A., Cranston, T., Rust, N., et al. (2016). Identification of a G-protein subunit- $\alpha 11$ gain-of-function mutation, Val340Met, in a family with Autosomal Dominant Hypocalcemia Type 2 (ADH2). J. Bone Miner. Res. 31, 1207-1214. doi: 10.1002/jbmr.2797

Pollak, M. R., Brown, E. M., Chou, Y. W., Hebert, S. C., Marx, S. J., Steinmann, B., et al. (1993). Mutations in the human $\mathrm{Ca}^{2+}$-sensing receptor gene cause familial hypocalciuric hypercalcemia and neonatal severe hyperparathyroidism. Cell 75, 1297-1303. doi: 10.1016/0092-8674(93)90617-Y

Pollak, M. R., Chou, Y. W., Marx, S. J., Steinmann, B., Cole, D. E. C., Brandi, M. L., et al. (1994). Familial hypocalciuric hypercalcemia and neonatal severe hyperparathyroidism. Effects of mutant gene dosage on phenotype. J. Clin. Invest. 93, 1108-1112. doi: 10.1172/JCI117062

Quinn, S. J., Ye, C. P., Diaz, R., Kifor, O., Bai, M., Vassilev, P., et al. (1997). The $\mathrm{Ca}^{2+}$-sensing receptor: a target for polyamines. Am. J. Physiol. 273(4 Pt 1), C1315-C1323.

Ray, K., and Northup, J. (2002). Evidence for distinct cation and calcimimetic compound (NPS 568) recognition domains in the transmembrane regions of the human $\mathrm{Ca}^{2+}$ receptor. J. Biol. Chem. 277, 18908-18913. doi: 10.1074/jbc.M202113200

Riccardi, D., and Brown, E. (2010). Physiology and pathophysiology of the calcium-sensing receptor in the kidney. Am. J. Physiol. Renal Physiol. 298, F485-F499. doi: 10.1152/ajprenal.00608.2009

Riccardi, D., Park, J., Lee, W. S., Gamba, G., Brown, E. M., and Hebert, S. C. (1995). Cloning and functional expression of a rat kidney extracellular calcium/polyvalent cation-sensing receptor. Proc. Natl. Acad. Sci. U.S.A. 92, 131-135. doi: 10.1073/pnas.92.1.131

Riccardi, D., Traebert, M., Ward, D. T., Kaissling, B., Biber, J., Hebert, S. C., et al. (2000). Dietary phosphate and parathyroid hormone alter the expression of the calcium-sensing receptor $(\mathrm{CaR})$ and the $\mathrm{Na}^{+}$-dependent $\mathrm{Pi}$ transporter (NaPi-2) in the rat proximal tubule. Pflugers Arch. 441, 379-387. doi: $10.1007 / \mathrm{s} 004240000436$

Riccardi, D., and Valenti, G. (2016). Localization and function of the renal calciumsensing receptor. Nat. Rev. Nephrol. 12, 414-425. doi: 10.1038/nrneph.2016.59

Richard, C., Huo, R., Samadfam, R., Bolivar, I., Miao, D., Brown, E., et al. (2010). The calcium-sensing receptor and 25-hydroxyvitamin D-1alpha-hydroxylase interact to modulate skeletal growth and bone turnover. J. Bone Miner. Res. 25, 1627-1636. doi: 10.1002/jbmr.58

Ritter, C. S., Haughey, B. H., Miller, B., and Brown, A. J. (2012). Differential gene expression by oxyphil and chief cells of human parathyroid glands. J. Clin. Endocrinol. Metab. 97, E1499-E1505. doi: 10.1210/jc.2011-3366

Ruat, M., Molliver, M. E., Snowman, A. M., and Snyder, S. H. (1995). Calciumsensing receptor: molecular cloning in rat and localization to nerve terminals. Proc. Natl. Acad. Sci. U.S.A. 92, 3161-3165. doi: 10.1073/pnas.92.8.3161

Salinger, E. M., and Moore, J. T. (2013). Perioperative indicators of hypocalcemia in total thyroidectomy: the role of vitamin $\mathrm{D}$ and parathyroid hormone. Am. J. Surg. 206, 876-881. doi: 10.1016/j.amjsurg.2013.08.020

Santa Maria, C., Cheng, Z., Li, A., Wang, J., Shoback, D., Tu, C., et al. (2016). Interplay between CaSR and PTH1R signaling in skeletal 
development and osteoanabolism. Semin. Cell Dev. Biol. 49, 11-23. doi: 10.1016/j.semcdb.2015.12.004

Schwarz, P., Sørensen, H. A., Transbøl, I., and McNair, P. (1992). Regulation of acute parathyroid hormone release in normal humans: combined calcium and citrate clamp study. Am. J. Physiol. 263, E195-E198.

Shoback, D. M., Membreno, L. A., and McGhee, J. G. (1988). High calcium and other divalent cations increase inositol trisphosphate in bovine parathyroid cells. Endocrinology 123, 382-389. doi: 10.1210/endo-123-1-382

Slatopolsky, E., Finch, J., Denda, M., Ritter, C., Zhong, M., Dusso, A., et al. (1996). Phosphorus restriction prevents parathyroid gland growth. High phosphorus directly stimulates PTH secretion in vitro. J. Clin Invest. 97, 2534-2540. doi: 10.1172/JCI118701

Tan, Y. M., Cardinal, J., Franks, A. H., Mun, H. C., Lewis, N., Harris, L. B., et al. (2003). Autosomal dominant hypocalcemia: a novel activating mutation $(\mathrm{E} 604 \mathrm{~K})$ in the cysteine-rich domain of the calcium-sensing receptor. J. Clin. Endocrinol. Metab. 88, 605-610. doi: 10.1210/jc.2002-020081

Tatsumi, R., Komaba, H., Kanai, G., Miyakogawa, T., Sawada, K., Kakuta, T., et al. (2013). Cinacalcet induces apoptosis in parathyroid cells in patients with secondary hyperparathyroidism: histological and cytological analyses. Nephron Clin. Pract. 124, 224-231. doi: 10.1159/000357951

Tfelt-Hansen, J., MacLeod, R. J., Chattopadhyay, N., Yano, S., Quinn, S., Ren, X., et al. (2003). Calcium-sensing receptor stimulates PTHrP release by pathways dependent on PKC, p38 MAPK, JNK, and ERK1/2 in H-500 cells. Am. J. Physiol. Endocrinol. Metab. 285, E329-E337. doi: 10.1152/ajpendo.004 89.2002

Thakker, R. V. (2004). Diseases associated with the extracellular calciumsensing receptor. Cell Calcium 35, 275-282. doi: 10.1016/j.ceca.2003. 10.010

Tsuchiya, D., Kunishima, N., Kamiya, N., Jingami, H., and Morikawa, K. (2002). Structural views of the ligand-binding cores of a metabotropic glutamate receptor complexed with an antagonist and both glutamate and Gd3+. Proc. Natl. Acad. Sci. U.S.A. 99, 2660-2665. doi: 10.1073/pnas.052708599

Vasher, M., Goodman, A., Politz, D., and Norman, J. (2010). Postoperative calcium requirements in 6,000 patients undergoing outpatient parathyroidectomy: easily avoiding symptomatic hypocalcemia. J. Am. Coll. Surg. 211, 49-54. doi: 10.1016/j.jamcollsurg.2010.03.019

Walter, S., Baruch, A., Dong, J., Tomlinson, J. E., Alexander, S. T., Janes, J., et al. (2013). Pharmacology of AMG 416 (Velcalcetide), a novel peptide agonist of the calcium-sensing receptor, for the treatment of secondary hyperparathyroidism in hemodialysis patients. J. Pharmacol. Exp. Ther. 346, 229-240. doi: 10.1124/jpet.113.204834
Ward, B. K., Magno, A. L., Davis, E. A., Hanyaloglu, A. C., Stuckey, B. G. A., Burrows, M., et al. (2004). Functional deletion of the calcium-sensing receptor in a case of neonatal severe hyperparathyroidism. J. Clin. Endocrinol. Metab. 89, 3721-3730. doi: 10.1210/jc.2003-031653

Westerdahl, J., Lindblom, P., Valdemarsson, S., Tibblin, S., and Bergenfelz, A. (2000). Risk factors for postoperative hypocalcemia after surgery for primary hyperparathyroidism. Arch. Surg. 135, 142-147. doi: 10.1001/archsurg.135.2.142

Wettschureck, N., Lee, E., Libutti, S. K., Offermanns, S., Robey, P. G., and Spiegel, A. M. (2007). Parathyroid-specific double knockout of Gq and G11 alpha-subunits leads to a phenotype resembling germline knockout of the extracellular $\mathrm{Ca}^{2+}$-sensing receptor. Mol. Endocrinol. 21, 274-280. doi: 10.1210/me.2006-0110

Windeck, R., Brown, E. M., Gardner, D. G., and Aurbach, G. D. (1978). Effect of gastrointestinal hormones on isolated bovine parathyroid cells. Endocrinology 103, 2020-2026. doi: 10.1210/endo-103-6-2020

Wise, A., Green, A., Main, M. J., Wilson, R., Fraser, N., and Marshall, F. H. (1999). Calcium sensing properties of the $\mathrm{GABA}_{\mathrm{B}}$ receptor. Neuropharmacology 38, 1647-1656. doi: 10.1016/S0028-3908(99)00119-7

Ye, C., Ho-Pao, C. L., Kanazirska, M., Quinn, S., Rogers, K., Seidman, C. E., et al. (1997). Amyloid-beta proteins activate $\mathrm{Ca}^{2+}$-permeable channels through calcium-sensing receptors. J. Neurosci. Res. 47, 547-554.

Young, S. H., Rey, O., Sinnett-Smith, J., and Rozengurt, E. (2014). Intracellular $\mathrm{Ca}^{2+}$ oscillations generated via the $\mathrm{Ca}^{2+}$-sensing receptor are mediated by negative feedback by PKC $\alpha$ at Thr888. Am. J. Physiol. Cell Physiol. 306, C298C306. doi: 10.1152/ajpcell.00194.2013

Zhang, C., Zhang, T., Zou, J., Miller, C. L., Gorkhali, R., Yang, J. Y., et al. (2016). Structural basis for regulation of human calcium-sensing receptor by magnesium ions and an unexpected tryptophan derivative co-agonist. Sci Adv. 2:e1600241. doi: 10.1126/sciadv.1600241

Conflict of Interest Statement: The author declares that the research was conducted in the absence of any commercial or financial relationships that could be construed as a potential conflict of interest.

Copyright (c) 2016 Conigrave. This is an open-access article distributed under the terms of the Creative Commons Attribution License (CC BY). The use, distribution or reproduction in other forums is permitted, provided the original author(s) or licensor are credited and that the original publication in this journal is cited, in accordance with accepted academic practice. No use, distribution or reproduction is permitted which does not comply with these terms. 